\title{
(ㄷ)
}

Research Paper

EPRA International Journal of Economic and Business Review-Peer Reviewed Journal

Volume - 9, Issue - 6, June 2021 | e-ISSN: 2347 - 9671| p- ISSN: 2349 - 0187

SJIF Impact Factor (2021): 8.302 || ISI Value: 1.433 || Journal DOI URL: https://doi.org/10.36713/epra2012

\section{DETERMINANTS OF STANDARDIZATION AND LOCALIZATION OF HUMAN RESOURCE MANAGEMENT (HRM) PRACTICES IN MULTINATIONAL COMPANIES' SUBSIDIARIES: A REVIEW AND IMPLICATIONS}

\author{
${ }^{1}$ Stephen James , ${ }^{2}$ Mawazo. H. Baruti \\ 1,2Institute of Rural Development Planning, P.O.BOX. 138, Dodoma
}

\begin{abstract}
DOI No: 10.36713/epra7190

Article DOI URL: https://doi.org/10.36713/epra7190

Standardization and localization are two debatable concepts in human resource management of Multinational Companies (MNCs) subsidiaries. Standardization involves conducting subsidiaries HRM practices in similar ways as conducted at headquarters of Multinational Companies while localization is adaptation of subsidiaries HRM practices to ways used by local firms in the host countries of subsidiaries. The objective of this paper was to explore determinants associated with standardization and localization of HRM practices in Multinational Companies' subsidiaries. Method used was a review of literature retrieved from Google, Google Scholar and Jstor as electronic data bases. Interpretation of findings from the literature showed that there were various determinants associated with standardization and localization of HRM practices in Multinational Companies' subsidiaries and mostly included: cultural and institutional factors, country-of-origin dominance and HRM approaches adopted by Multinational Companies for overseas subsidiaries. It was concluded that the national contexts of the parent and host countries as reflected in the individual determinants had a huge role to play in standardization and localization of HRM practices such as staffing, training and development, compensation, communication, job design, promotion, recognition, job security, industrial relations, and performance management among MNCs' subsidiaries. The paper also provided implications to international human resource management practitioners.
\end{abstract}

KEY WORDS: HRM practices, Localization, Standardization, Subsidiaries

\subsection{INTRODUCTION}

Standardization and localization of HRM practices are essential concepts in human resource management of Multinational Companies' (MNCs') subsidiaries. As MNCs' establish subsidiaries beyond borders of the parent country to produce services and goods, they experience complex situation related to management of human resources far away from their parent countries (Kim and Milnerz, 2019). Some scholars like Rugman et al. (2000) 
and Humes (1993) have argued that the experience they face in the host countries is a dilemma on whether they should standardize or localize HRM practices overseas. Eventually, MNCs' subsidiaries decide to implement either high degree of standardization or localization across HRM practices.

Standardization of HRM practices refers to centralized decision making at MNCs' headquarters regarding HRM practices at subsidiaries; and conduct them in the same way as done in their parent countries (Muritiba et al., 2010). Standardization of HRM is considered by Smale (2008) and Taylor (2006) as a global HRM integration in which MNCs try to achieve common standards of HRM management between the headquarters (HQ) and the business affiliates around the world. It can be implemented by exporting similar mechanisms of HRM practices from headquarters (HQs) to subsidiaries operating in the host countries. Al-Khaldi (2016) used the concept of standardization interchangeably with transfer of HRM practices from headquarters to the subsidiaries while Uyasal (2014) and Sparrow (2016) viewed it as a convergence of HRM practices between the parent company and subsidiaries.

In contrast, localization of HRM practices refers to local adaptation where MNCs adapts HRM practices to host country's local firms' practices (Chung and Furasawa, 2015). Localization is diverged HRM practices from the parent country of the MNCs to local conditions of host nations (Budhwar et al., (2016). Sometimes localization is used synonymously with the concept of decentralization of Human Resource Management practices in which the subsidiaries become autonomous in executing Human Resource (HR) functions differently from the headquarters but addressing business goals of the MNCs (Tihanyi et al., 2012). In other words, localization is a practical effort of indigenizing international HRM practices to host country conditions.

HRM practices that should have been standardized or localized by MNCs' subsidiaries may be highlighted in the Ability, Motivation, Opportunity and Control (AMO) framework (Al-Tit, 2020; Garcia-Marin and Tomas, 2016). Based on the AMO framework, HRM practices may consist of a wide range of ability enhancing practices such as recruitment and selection (staffing), training and development. They may further consist of motivation enhancing practices including practices such as compensation policy, job security and recognition programmes. AMO framework further indicates that Opportunity practices which include practices like communication with employees, job design, and level of internationalization, team working, employee involvement and promotion can be standardized or localized by subsidiaries. Control practices involves of performance appraisal, variable pay and global competency assessment. Then, this paper's focus has been on standardization and localization of HRM practices based on several practices being proposed by the AMO framework.

Apart from an attempt to understand the concepts of standardization, localization and what constitute HRM practices, it has been noted that there have been many studies conducted on standardization and localization of HRM practices especially in Europe, Northern America, China, Japan, Australia and South Africa. For instance, Belizón et al. (2016) found that HRM practices including pay, fringe benefits, performance appraisal; succession planning had high degree of standardization in Ireland and Spain among 450 MNCs subsidiaries. Indian Information Technology MNCs in Australia standardized many elements of compensation but also adapted several aspects of compensation to local host country practices (Kyurova, 2019). Chang et al. (2009) almost revealed similar findings in which four Taiwanese MNCs' subsidiaries in United Kingdom (UK) standardized staffing by employing Taiwanese top managers and conducted performance management for British local employees on individual basis based on the British local firms practices.

As MNCs' subsidiaries were engaging in standardization and localization of HRM practices in the subsidiaries, there has been inadequate knowledge on determinants of standardization and localization of HRM practices in MNCs' subsidiaries in the literature published in the developing world. Therefore, the objective of this paper was to explore determinants associated with MNCs' subsidiaries' standardization and localization of HRM practices based on perspectives of literature review. The paper would facilitate accessibility of information on determinants of standardization and localization of HRM practices among practitioners and international human resource management students.

\subsection{METHODS}

\subsection{Process and Literature Search}

Preparation of this paper was preceded by search of online articles published on standardization and localization of HRM practices in MNCs' subsidiaries. A total of 62 articles were obtained from Google (17 articles), Google Scholar (32 articles) and Jstor (13 articles) as data bases. The key terms that were used during search of articles were: "standardization of HRM", "localization of HRM", "HRM transfer", "global standardization of HR", "HRM convergence", "HRM divergence ", "integration of HRM practices", "Multinational Companies" and "Subsidiaries". All articles that were searched from the internet data bases were stored on personal computer for later selection and subsequent review. 


\subsection{Selection Process and Criteria for Inclusion}

Research articles which were selected consisted of those published not more than the past 13 years. The decision to review articles published in the respective period between 2007 and 2020 was reached in order to get representative sample of articles and saving time for not reviewing too many articles published beyond the past 13 years. A total number of articles selected for the review on determinants of standardization and localization of HRM practices was 20 out 62 . Ultimately, nine qualitative research articles, ten quantitative articles and two mixed methods research articles were reviewed. All articles reviewed were published on standardization and localization of HRM practices among MNCs' subsidiaries operating in some African countries, North American countries, European and Asian countries.

\subsection{FINDINGS ON DETERMINANTS ASSOCIATED WITH STANDARDIZATION AND LOCALIZATION OF HRM PRACTICES IN MNCs' SUBSIDIARIES \\ 3.1. Cultural and Institutional Factors}

Similar cultural factors such as social norms, customs, traditions and values existing between the parent country of a MNC and subsidiary host country influence high degree of standardization across HRM practices. Maharjan and Sekiguchi (2017) found that Japanese MNCs' subsidiaries in India managed to standardize performance appraisal, seniority based promotion and performance-based pay because Japanese and Indian culture were similar being characterized by the same social norms, valuing seniority, high power distance and long term orientation as summarized in Table 1 on appendices. Japanese and South Korea MNCs 'subsidiaries as found by Chung et al. (2015) standardized staffing by employing parent country nationals at top of managerial positions in European markets due to cultural considerations. They trusted the parent country nationals because they could communicate in Japanese language with the companies' headquarters in Japan as opposed to Europeans in Europe.

In contrast, Ouyang et al. (2019) found that Chinese MNCs subsidiaries in USA were locally adapting their human resource management practices due to cultural differences between USA and China. Butt and Katuse (2007) also found that foreign MNCs' in Automobile industry in Pakistan were localizing HRM practices due to cultural challenges as summarized in Table 1 on appendices. Similarly, Chen et al. (2005) further found that cultural dissimilarity of the home country among MNCs from America and Europe influenced HR local adaptation strategy of subsidiaries in Taiwan.

Closely linked to culture are the institutional factors of which it has been found that countries such as the United Kingdom (UK), Canada, Spain, Denmark and Norway have different institutional pressure issued to MNCs operating in areas of jurisdiction (Edwards et al.,2016). Ayentimi et al. (2018) as summarized on Table 1 on appendices found that there were three dimensions in the institutional pressure being proposed in institutional theory. The first dimension of the institutional pressure was regulations followed by cognitive and normative dimensions. Regulations were directly related to formal legal systems constituting the coercive legislations which imposed sanctions on violation of their provisions on people management in organizations.

The cognitive dimension in the institutional environment, involved a predetermined social behaviour patterns that were accepted in host country as a whole. The normative dimensions consisted of norms and values formulated by societal institutions such as religious organizations, universities, research institutions, trade unions, consultancy firms, professional and business bodies regarding management of employees. Gooderham et al. (2019) found that institutional differences between countries constrained MNCs from adopting worldwide HR policies but rather tended to diverge them based on local institutions of the host country.

The other institutional factors that influence standardization and localization of HRM practices are the varieties of capitalism consisting mainly of Liberal Market Economies (LMEs) and Coordinated Market Economies (CMEs) as found by Farndale et al., (2017) in an article on effects of market economy and foreign Multinational Enterprises' subsidiaries' convergence and divergence of HRM. Farndale et al. (2008) found that LMEs provided greater autonomy to companies to strategize for maximization of profits for shareholders through deregulation of labour markets, strong competition and reduction of government interference whereas CMEs' were dominated by higher regulation and control of companies by legislative institutions, stakeholders and the state.

HRM practices such as financial participation; employee voice, corporate information sharing, employee contracting, and commitment to training were more localized in Germany, Belgium, the Netherlands, Austria, Denmark and Sweden as they constituted CMEs' unlike USA, UK and Australia which represented the liberal market economies. In connection to LMEs' and CMEs, Parry et al., (2017) as displayed by Table 1 on appendices found that HR practices including selection sophistication, investment in training, individualized rewards, diversity programmes, trade union recognition, direct communication, indirect communication followed by North American owned MNCs' subsidiaries varied widely depending on whether these North American owned MNCs were operating in liberal or coordinated market economies. 


\subsection{Country- of- Origin Dominance}

Edwards et al. (2013) found that country - of-origin dominance in the world economy influenced standardization of management practices among MNCs' subsidiaries. Pudelko and Wil-Harzing (2007) found that the overall results among MNCs' subsidiaries originating from the US, Japan and Germany were converging practices to the US HRM practices because the US has been a dominant economy setting global best standards in human resource management as summarized in Table 2 on appendices. Whenever, a parent country of a Multinational Company took a relatively advanced economy, its MNCs' subsidiaries did HRM practices in the same way as their parent company headquarters. France is a long standing economic power compared to China, and in this regard Jiang and Yahiaoui (2019) also found that majority of 16 French companies were standardizing their HRM practices in China due to country-of-origin dominance in terms of industrial and HRM experience.

Savaneviciene and Kersiene (2015) further found that USA as being more economically powerful had its majority of MNCs' subsidiaries standardizing leadership training, training programmmes, employee rigorous selection procedures, cross-cultural competence development, workforce competence evaluation, employee development models, compensation, staff motivation and employee engagement in Lithuania. This is a result of USA MNCs' belief that the US models of human resource management were the global best practices for subsidiary staff performance in a country having weaker economy. Additionally, Cocul'ová (2015) found that a country with transition economy, unimpressive rate of unemployment and economic challenges were likely to accept standardization of HRM practices among subsidiaries whose parent companies were originating from powerful economy.

\subsection{International HRM Approaches Adopted by Multinational Companies}

International HRM approaches that were adopted by Multinational Companies for host countries determined the level of standardization and localization of HRM practices. In support of this assertion, Azungah (2017) as summarized in Table 3 on appendices found that Western MNCs' subsidiaries operating in Ghana standardized succession planning, training and development, contingent reward and employee participation because of ethnocentric approach used by Western Multinational Companies in Ghana. Similarly, Smerek et al. (2018) found that MNCs' subsidiaries in the Republic of Slovakia either standardized or localized HRM practices because of ethnocentric and polycentric approaches adopted by companies for HRM in the subsidiaries.

A single case study of the French Multinational Company also was found by Touron (2008) changing its ethnocentric to geocentric model by staffing top managerial positions with foreign candidates from wherever they were available because of the inefficiency posed by ethnocentric approach. Further study by Sarafin and Szamosi (2015) in a global luxury US hotel chains in Azerbaijan, Kyrgyzstan and Germany revealed that overall, the luxury hotel subsidiaries had uniform implementation of HRM policies regardless of locations' socio-economic differences; but uniformity of HRM being facilitated by a geocentric approach.

\subsection{DISCUSSION}

Based on the review of literature, it was found that there were various determinants associated with standardization and localization of HRM practices in MNCs' subsidiaries. MNCs' subsidiaries operating overseas would localize many of their HRM practices including: staffing, training and development, compensation, industrial relations, employee communication, employee participation, health and safety due to cultural differences in the host countries. Several researchers including Myloni et al. (2004), Edwards and Kuruvilla (2005) and Mellahi et al. (n.d) also found that host country culture such as traditions, norms, and values limited standardization and transfer of HRM practices to subsidiaries. HRM practices at subsidiaries were conducted based on intangible and tangible cultural contexts of the host nations for them to succeed in their global business strategy, gain allegiance, legitimacy and avoid resentment from the local society.

But as cultural factors facilitated local adaptation of HRM practices in the subsidiaries, it has been found that similarities in culture again may influence standardization or transfer of HRM practices from parent to host countries of subsidiaries. As already indicated above, Maharjan and Sekiguchi (2017) in their findings on Japanese HRM standardization in terms of seniority-based promotion and performance-base pay in India was based on cultural similarities characterized by common social norms, long-term orientation, valuing more seniority and high power distance which eased transfer of HRM practices by Japanese subsidiaries in India.

Based on the findings above, it is clear that MNCs' subsidiaries which operated in countries which had similar culture with the parent HQs easily standardized HRM practices as cultural similarities between country-oforigin and the host countries do not pose barriers to standardization. The findings suggested that MNCs which established their investments in environments with relatively similar culture would have high degree of standardization in most of their HRM practices. For this case, the British MNCs' subsidiaries in Ghana as already 
found above standardized because of the fact that Ghana's national culture was similar to some extent with the British culture due to colonial ties, Anglophone and commonwealth culture across these two countries.

Likewise, the institutional factors in terms of labour laws, regulations, cognitive and normative dimensions imposed by institutions determined a degree of MNCs' subsidiaries' standardization or localization of HRM practices. Differences in the labour laws, regulations, rules, ideas, norms and values which evolved as institutional pressures in the host country limited standardization in favour of local adaptation of HRM practices. Some scholars including Björkman et al. (2006) and Sparrow (2009) also found that all matters relating to MNCs behaviourchoices about subsidiary location and organisation, technology, capital, labour, strategies, investments and HR practices were often influenced by the institutional differences. However, Edwards et al. (2009) argued that sometimes the home country institutional perspectives could influence standardization by imposing appropriate practices and demanding institutional change in the host countries.

Other institutional factors which enabled MNCs' subsidiaries to either standardize or localize HRM practices were embedded in varieties of capitalism which consisted of Liberal Market Economies (LMEs) and Coordinated Market Economies (CMEs) as found by scholars such as Farndale et al. (2008) above. It was clearly shown by the findings that minimal government role, labour market deregulation and companies' autonomy in LMEs' in some countries such as USA and the UK supported MNCs in extending the parent country HRM practices to host countries' subsidiaries. As opposed to LMEs, CMEs' had their labour markets highly regulated and controlled by the state, legislative institutions and stakeholder involvement which made it difficult for MNCs' subsidiaries to standardize their home country practices in Germany, Denmark, Sweden, Finland, the Netherland and Austria in Europe. These findings were supported by Kuznetsov and Jacob (2015) who found that organizational practices in subsidiaries differed from those in the parent companies as a result of varieties of capitalism based on liberal and coordinated market economies.

It was also found that country-of-origin dominance in terms of the economic aspects like the financial position, industrial technological experiences and HRM experiences all limited local adaptation in favour of standardization of HRM practices. Although China was emerging as one among the most economic powers, USA as a dominant economy which sets standards for global best practices in the world economy was still prevalent. This situation made MNCs' subsidiaries diffuse HRM practices from USA due to her technological advancement and modern organizational management practices. Pudelko and Wil-Harzing (2009) found supportive findings which showed that the American system served as powerful sources of inspiring the Japanese human resource management possibly because of economic power imbalance between the two countries.

Apart from country-of-origin dominance, the literature further showed that international human resource management approaches adopted by Multinational Companies' headquarters for subsidiaries determined the implementation of standardization and localization across HRM practices. There were four popular approaches to this case and they included: ethnocentric, geocentric, regiocentric and polycentric approaches. In ethnocentric approach, the MNCs insisted on business and management uniformity between MNCs' headquarters and subsidiaries; which in turn forced the subsidiaries to use similar HRM practices of the parent company (Tiwari, 2013; Hannon, 1994).

In geocentric approach to human resource management, MNCs usually thought of global in terms of operations and ignored nationality boundaries in favour of global standardization (Crawshaw et al., 2017). As found by Wilks and Vebeke (2016) and Pudelko and Wil-Harzing (2008) in support of the secondary data reviewed, MNCs subsidiaries in geocentric approach as an example would employ the host country national (HCN), homecountry nationals and third country nationals based on the job-person-fit model irrespective of where they originate. Many of their HRM practices were globally integrated with some levels of localization to address local responsiveness (Caligiuri and Stroch, 2006). As already found by Touron (2008) above geocentric approach to HRM was highly interconnected with the current globalization forces where movements of people and investments could be employed and established in any part of the world regardless of geographical boundaries making it easier to employ staff from where they were available around the world. As opposed to geocentrism, regiocentric approach to HRM usually standardized HRM practices at regional level as Giousmpasoglu and Marinakou (2017) wrote:

"...it indicates that each subsidiary should adapt to host location's practices, but

for a geographical region rather than a single country and also attempts to achieve

consistency across this region, instead of across the world" p.7

With regiocentric approach, regions such as Africa, Europe, North America, and Middle East could deploy the same staffing, training and development, Human Resource Management Information System (HRMIS) software, career management, compensation management and performance appraisal within regional jurisdiction without beyond extension. Regiocentric approach posed advantages such as allowing career progression, transfer of staff from one country to another within a region, permit international and cross-culture experience at regional level rather than at world level by acting between ethnocentric and geocentric approaches. 
As three approaches above influenced standardization of HRM practices among MNCs' subsidiaries in different ways, polycentric approach underscored the fact that it influenced higher localization of HRM practices. Based on this approach MNCs' subsidiaries totally followed the local practices as conducted in local companies of the host nations (Oppong, 2017; Isiaka et al., 2016; Lakshman, 2013). If a MNCs'subsidiary was located in Country $\mathrm{X}$, it would adapt HRM practices such as staffing, training and development, compensation, industrial relations to Country Y HRM practices. Polycentric approach as it concentrated on local adaptation of HRM practices, it presented numerous advantages such as increasing representation of local practices in global organization, reduced labour costs, demonstrated trust in local nationals, increased legitimate perception of subsidiaries and reduction on the amount of control exercised by headquarters (Goegele, 2020; Treven, 2001).

\subsection{CONCLUSION}

This paper sought to explore determinants associated with standardization and localization of HRM practices in MNCs' subsidiaries. It was revealed that generally standardization and localization of HRM practices in MNCs' subsidiaries were influenced by national contexts. Different contexts in terms of culture and institutional environment between the parent (home) and host countries had a tendency to heighten localization of HRM practices in subsidiaries as opposed to similarities. In addition, approaches to HRM in the host countries and country-of-origin economic dominance determined whether MNCs' standardize or localize its HRM practices in overseas subsidiaries. With recognition of host countries' culture and their institutions in today's world, it is anticipated that possibly the cultural and institutional determinants had a huge role to play in HRM of MNCs' subsidiaries around the world.

\subsection{IMPLICATIONS}

Similarities and differences of culture and institutional dimensions such as the labour regulations, cognition and normative institutional dimensions will pose pressure on International Human Resource Managers to either standardize or localize HRM practices. Subsidiary host countries which have similar culture and institutional environment will have to standardize HRM practices with a parent country because similar culture and institutions remove barriers to standardization. In this sense, HR practices like recruitment and selection, training and development, succession planning, compensation, industrial relations and performance management will be conducted by International Human Resource Managers in the same way as done at the headquarters. However, huge differences in terms of culture and institutions between the host and parent country will demand International Human Resource Managers to localize most of HRM practices. Compliance to local environment will increase respect to subsidiaries and avoid unnecessary resentment from the local authorities.

Economic dominance by the parent country of the subsidiaries will have also greater influence on International Human Resource Managers' standardization of HRM practices. Countries like USA, China, United Kingdom and Scandinavian possess resources like finance, technology and more experiences in HRM. Being economically powerful than most countries in the developing world, they believe that they are setters of global HRM practices. In this endeavour, subsidiaries' HRM practices will remain controlled from parent headquarters for many subsidiaries especially in the developing world.

Nevertheless, approaches to HRM adopted by MNCs headquarters still will remain key players that will force International Human Resource Managers to standardize or localize HRM practices. For MNCs' subsidiaries that originate from a parent company which implement ethnocentric approach will impose standardization of HRM practices among managers at subsidiaries. International Human Resource Managers working at MNCs' subsidiaries being established by a company that deploys polycentric approach will have to adapt HRM practices to host countries conditions. For example, staffing, salary, fringe benefits, industrial relations and social security schemes will be adapted to local practices. International Human Resource Managers at subsidiaries will engage in globally integrated practices under MNCs which implement geocentric approach. Such managers for example will have to procure employees from any part of the world through competitive recruitment and selection processes. This situation will take place because geocentric approach has a global focus using similar practices whereas regiocentric approach will demand International Human Resource Managers to localize their HRM practices at regional level as opposed to polycentric approach which adopt local adaptation of HRM at country level. 


\section{REFERENCES}

1. Adams. K, Nyuur. R.B, Ellis. F.Y.A and Yaw. D. (2017). South African MNCs' HRM Systems and Practices at the Subsidiary Level: Insights From Subsidiaries in Ghana. Journal of International Management. 23. (2). pp.180-193

2. Al-Khalidi.A. H. (2016). The Transfer of HRM Policies and Practices in American Multinational Hotels in Saudi Arabia. Doctorate Thesis. Curtin University

3. Al-Tit.A.A. (2020). The Impact of AMO-HR Systems on Proactive Employee Behaviour: The Mediating Contribution of Leader-Member and Team-Member Exchange. International Journal of Engineering Business Management. Vol. 12: 113

4. Anali. E, Ratković. T and Orlić. (2015). Transfer of Performance Appraisal Practices from MNC Parent to Subsidiaries in Serbia.

5. Ayentimi.D.T, Burgess.J and Dayaram.K. (2017). Do Multinational Subsidiaries Demonstrate a Convergence Across their HRM Practices in a less developed Host-Country?: Evidence from Ghana. Employee Relations. Vol. 39. Issue. 7. pp. $1066-1082$

6. Azungah.T. (2017). Strategic Human Resource Management Practices of Western MNEs in Africa: Standardization, Localization or both?. Journal of Business Studies. Vol. 4. Issue. 1. pp. 17

7. Belizón, M.J., Morley, M.J. and Gunnigle, P. (2016), "Modes of integration of human resource management practices in multinationals", Personnel Review, Vol. 45 No. 3, pp. 539-556

8. Björkman. I and Lervik. J. E. (2007). Transferring HR practices within multinational corporations. Human Resource Management Journal, Vol 17, no 4, pages 320-335

9. Björkman. I, Fey. C.F, Park. H.J. (2006). Institutional Theory and MNC Subsidiary HRM Practices: Evidence from a Three Country Study. SSE Russia Working Paper. No. 6-102

10. Budhawar.P, Varma.A and Patel.C. (2016). Convergence-Divergence of HRM in the Asia-Pacific: Context-Specific Analysis and Future Research Agenda. Elsevier

11. Butt. M.A and Katuse. P. (2017). International Human Resources Management Practices in Automotive Industry in Pakistan: Implications for Economic Growth. International Journal of Business and Management. Vol. 12. Issue. 2,

12. Caligiuri.P.M and Stroch.L.K. (2006). Multinational Corporation Management Strategies and International Human Resource Practices: Bringing IHRM to the Bottom Line. The International Journal of Human Resources Management. Vol. 6, 1995. Issue. 3

13. Chang. Y. Y and Mellahi.K. K and Wilkinson. A. (2009). Control of Subsidiaries of MNCs from Emerging Economies in Developed Countries: The Case of Taiwanese MNCs in the UK

14. Chen. S, Lawler. J.J and Bae. J. (2005). Convergence in Human Resource Systems: A Comparison of Locally Owned and MNC Subsidiaries in Taiwan. Human Resource Management. Vol. 44, pp. 237-256

15. Chung . C and Furasawa. M. (2015). The HRM of Foreign MNCs Operating in Europe. Discussion Paper. University of Reading

16. Crawshaw. J, Budhawar.P, Davis. A. (2017). Human Resource Management: Strategic and International Perspectives. Los Angeles. USA.

17. Edwards. P, Sanches-Mangas. R, Tregaskis.O, Levesque.C, Mcdonnell.A, Quintanilla. J. (2013). Human Resource Management Practices in the Multinational Company: A Test of System, Societal and Dominance Effects. Industrial and Labour Relations

18. Edwards. T and Kuruvilla. S. (2005). International HRM: National Business Systems, Organizational Politics and the International Division of Labour in MNCs. Inter. J. of Human Resource Management. Vol. 16. No. 1 pp. 1-21

19. Edwards. T, Mangas. R, Jalette. P, Lavelle.J, Manbaeva.D.B. (2016). Global Standardization or National Differentiation of HRM Practices in Multinational Companies?: A Comparison of Multinationals in Five Countries.

20. Edwards. G, Shyder. G and Fortwengel. J. (2019). Mapping the Impact of home-based-and-host-country institutions on human resource management in emerging market multinational companies: A Conceptual framework. Thunderbird International Business Review.

21. Edwards.T and Kuruvilla.S. (2005). International HRM: National Bussiness Systems, Organizational Politics and the International Division of Labour in MNCs. International Journal of Human Resource Management. Vol.16. Issue.1. pp.1-21.

22. Farndale, Brewester.C and Poutsma.E. (2008). Coordinated Vs. Liberal Market HRM: The Impact of Institutionalization on Multinational firms. The international Journal of Human Resource Management. Vol 19 No. 11, 2004 - 2023

23. Farndale, Brewester.C, Ligthart. P and Poutsma.E. (2017). The Effects of market Economy and Foreign MNSs' subsidiaries on the Convergence and Divergence of HRM. Journal of International Business Studies. 48(9). Pp.1065 1086

24. Farndale. E and Paauwe. J. (2007). Uncovering Competitive and Institutional Drivers of HRM Practices in Multinational Corporations

25. Garcia-Marin.J.A. and Tomas.J.M. (2016). Deconstructing AMO framework: A Systematic review: Intangible Capital. 12(4); 1040 
26. Giousmpasoglu.C and Marinakou. E. (2017). Culture and Managers in a Globalized World in Pablos. P.O. and Tennyson.R.D. (2017). Handbook of Research on Human Resources Strategies for the New Millennial Workforce. IGI Global. USA.

27. Goegele. (2020). A Polycentric Perspective on United Nations: Prepared for delivery at the International SDG Research Symposium, Utrecht, The Netherlands.

28. Gooderham, P. N., Mayrhofer, W. and Brewster, C. (2019) A framework for comparative institutional research on HRM. The International Journal of Human Resource Management, 30 (1). pp. 530.

29. Hannon. J.M, Huang.I.C, Jaw.B.S. (1994). International Human Resource Management Strategy and Control: The Case of Multinationals and Their Subsidiaries. Centre for International Bussiness Education and Research. Purdue University.

30. Harjo.E.B. (2015). Gaining Competitiveness in the Global Business World through the Implementation of International Human Resource Management. 3rd International Seminar and Conference on Learning Organization (ISCLO)

31. Harry. E \& Collings . D.G. "Localization: Societies, organizations and employees in Scullion. H \& Collings D.G. (2006) . (ed). Global Staffing. Routledge. New York. USA p-139

32. Humes, Samuel. (1993). Managing the multinational confronting the global-local dilemma. Prentice Hall

33. Isiaka.S.B, Aliyu.M.O, Abogurin.A.P, Aremu.N.S, Abdullah.A.s. (2016). A Conceptual Analysis of Global Human Resource Practices: Challenges and Prospects. $3^{\text {rd }}$, International Conference on African Development Issues (CUICADI)

34. Jiang. C and Yahiaoui. D. (2019). French Multinational Companies' HRM in China: Strategic Orientation and Integration Approaches. Journal of Asia Pacific Business Review. Vol. 25, Issue.1

35. Josef, Frank, Arne.H, Mathew. A.M.C, Voronkova.S. (n.d). Employee Relations in Multinational Companies. Employee Relations in Foreign Owned Subsidiaries. pp.25-36

36. Kim. S and Milnerz. H.V. (2019). Multinational Corporations and their Influence Through Lobbying on Foreign Policy. www.brookings.edu. Retrieved on 27/08/2020

37. Kuznetsov. A and Jacob. (2015). Convergence versus Divergence: Testing Varieties of Capitalism Perspectives on the Globalization of Business Practices. In S. Marinova (ed). Institutional Impacts on Firm Internalization. (2015). Palgrave Macmillan, pp.12-39

38. Kyurova.A. (2019). Local Adaptation Versus Global Integration of Pay and Rewards Practices Among MNCS. Entrepreneurship. Vol. VII, Issue.2. pp.153 - 161

39. Lakshman. S. (2013). Multinational Companies' Executive Selection Practices; Challenges of Human Resources in International Business Management. Conservatoire National Arts et Métiers.

40. Maharjan. M.P and Sekiguchi. T. (20017). Human Resources Management Practices of Japanese Companies in India: Leading with the Transfer-Adaptation Dichotomy. Journal of Asia Business Studies

41. Marin-Garcia. J.A. and Tomas. J. M. (2016). Deconstructing AMO framework: A systematic review. Intangible Capital. 12(4): 1040-1087

42. Mcgraw. P. (2004). Negotiation of HRM Practices in Australian Subsidiaries of Overseas MNCs. Paper presented at Multinational and International diffusion of organizational forms and practices. IESE. Barcelona ppl-23 pdf. Retrieved on 7/6/2016.

43. Mellahi. K, Demirbag. M, Collings. D.G, Tatoglue. E and Hughes. M. (n.d).Similarly Different: A Comparison of HRM Practices in MNE Subsidiaries and Local Firms in Turkey

44. Mellahi.K; Frynas.J.G and Collings.D.G. (2015). Performance Management Practices within emerging Market Multinational Enterprises: The Case of Brazilian Multinationals.

45. Mia.E and Suutari. V. (2003). HRM in foreign Affiliates: A Multiple Case Study among Estonian Affiliates of Finnish Companies. Journal of East European Management Studies. Vol. 9, Issue.4, pp. 345-366

46. Muritiba.P.M, Muritiba.S.N, Compariario.M and Albuquerque.L.G. (2010). International HR Strategy in Brazilian Technology Multinationals. Brazilian Administration Review. E-ISSN: 1807 - 7692

47. Myloni. B, Wil-Harzing. A and Mirza.H. (2004). Host country specific factors and the transfer of human resource management practices in multinational companies. International Journal of Manpower. Vol.25. No. 6

48. Nakhile. S. (2011). The Transfer of Human Resource Practices from American and European Multinational Companies to their Lebanese Subsidiaries. A Study of the Host-Country Effects and of Standardization-Adaptation Dilemma. Phd Thesis. Faculty of Economics and Social Sciences. University of Fribourg. Switzerland pp.10-13

49. Oppong.N.Y. (2017). Human Resource Management Transfer Challenges within Multinational firms: From Tension to best-Fit. Management Research Review. Vol. 41, No.7, pp. 860 - 877

50. Ouyang. C, Liu. M, Chen. Y, Li. J and Qin. W. (2019). Overcoming Liabilities of Origin: Human Resource Management Localization of Chinese Multinational Corporations in Developed Markets.

51. Parry.E, Dickmann.M, Morley.M. (2008). North American MNCs and the HR Policies in Liberal and Coordinated Market Economies. The International Journal of Human Resource Management. Vol.19. No.11, 2024 - 2040

52. Pudelko. $M$ and Wil-Harzing. A. (2007). Country-of-Origin, Localization, or Dominance Effects? An Empirical Investigation of HRM Practices in Foreign Subsidiaries. Human Resource Management, Winter 2007, Vol. 46, No. 4, Pp. 535-559

53. Pudelko. M. and Wil-Harzing.W. (2009). Japanese Human Resource Management: Inspirational from Abroad and Current Trends of Change. International Human Resource Management in Japan. Routledge 
54. Pudelko.M and Wil-Harzing.A. (2008). The Golden Triangle for MNCs: Standardization Towards Headquarters Practices, Standardization Towards Global Best Practices and Localization

55. Ratković.T and Orlić. R. (2015). Transfer of Performance Appraisal Practices from MNC Parent to Subsidiaries in Serbia. Economic Annals. Vol. LX, NO.204

56. Rosenzweig. P.M and Nohria.(1994). Influences on Human Resource Management Practices in Multinational Corporations. Journal of International Business Studies, SECOND QUARTER

57. Rugman .A. M; Collinson.S and Hodgetts.R.M. (2000). International Business. $4^{\text {th }}$ Edition. Pearson Education Limited

58. Sarafin.G.O and Szamosi.L.T. (2015). Five Star Hotel of a Multinational Enterprise in Countries of the Transnational Periphery: A Case Study in Human Resource Management.

59. Savaneviciene. A and Kersiene. K. (2015). How are HRM practices transferred in MNCs? Lithuania case. Procedia Economics and Finance 26. pp. $982-990$

60. Shamsul.A, Shariful.A, Rakibul.I and Munmun.R. (2019). High-performance work systems and job engagement: The mediating role of psychological empowerment. Cogent Business \& Management, 6: 1664204.

61. Smale. A. (2008). Global HRM integration: a knowledge transfer perspective. Personnel Review. Vol. 37 No. 2. pp. 145-164

62. Smerek. L, Sekova. M, Vetrakova. M. (2018). Convergence and Divergence in Human Resources Management in Selected Companies in the Slovak Republic. International Journal of Multidisciplinary in Bussiness and Sciences. Vol. 5, No. 8

63. Sparrow. P, Schuler.R.S, Jackson.S.E. (2006). Convergence and Divergence: Human Resource Practices and Policies for Competitive Advantage Worldwide. The International Journal of Human Resource Management. Vol. 5. Issue. 2

64. Sparrow. P. (2009). "Integrating People, Process, and Context Issues in the Field of IHRM in Sparrow. P.R. (2009). (ed). Handbook of International Human Resource Management.

65. Susaeta and Pin. J.R. (2008). The Five Phases in the Transfer of HR Policies and Practices within MNCs. University of Navarra. Spain

66. Taylor. S. (2006). Emerging Motivations for Global HRM Integration: In A. Ferner et al. (eds.), Multinationals, Institutions and the Construction of Transnational Practices. Palgrave Macmillan, a division of Macmillan Publishers Limited

67. The United Republic of Tanzania. (2008). National Employment Policy. Ministry of Labour, Employment and Youth Development. Dar es Salaam

68. Tihanyi.L, Swaminathan. A, Soule.S.A. (2012). International Subsidiary Management and Environmental Constraints: The Case for Indigenization. Advances in International Management. Vol.25 pp. 373-397

69. Tihanyi.L, Swaminathan. A, Soule.S.A. (2012). International Subsidiary Management and Environmental Constraints: The Case for Indigenization. Advances in International Management. Vol.25 pp. 373-397

70. Tiwari. N. (2013). Managing Human Resources in International Organizations. Global Journal of Management and Business Studies. Vol. 3, No. 4, pp. 355-360

71. Touron.M.M. (2008). From an Ethnocentric to Geocentric Approach to IHRM: The Case of French Multinational Company. Cross-Cultural Management An International Journal 15(4) 335-352

72. Treven.S. (2001). Human Resource Management in International Organizations. Management. Vol.6. 1-2. pp. 177-189

73. Uyasal. (2014). Convergence or Divergence between European HRM and American HRM. Journal of Business and Economics. Vol.5, No.10, pp.1923-1928 
APPENDIX: Division of Articles as per themes and Area of Study

Table 1: Cultural and Institutional Factors Determining Standardization and Localization of HRM Practices in MNCs' Subsidiaries

\begin{tabular}{|c|c|c|c|c|c|}
\hline $\begin{array}{l}\text { Author(s) } \\
\text { and Year }\end{array}$ & Method & Tools & Sample & Summarized Findings & Country \\
\hline $\begin{array}{l}\text { Maharjan } \\
\text { and } \\
\text { Sekiguchi } \\
\text { (2017) }\end{array}$ & Qualitative & $\begin{array}{l}\text { Semi-structured } \\
\text { Questionnaire }\end{array}$ & $\begin{array}{l}\text { Japanese MNCs } \\
\text { subsidiaries in } \\
\text { India }\end{array}$ & $\begin{array}{l}\text { Similar cultural characteristics and social norms } \\
\text { between India and } \\
\text { Japan played a critical role in forming standardized } \\
\text { performance appraisal, seniority-based promotion, } \\
\text { and performance-based pay due to common social } \\
\text { norms, valuing seniority and high power distance }\end{array}$ & India \\
\hline $\begin{array}{l}\text { Ouyang et al., } \\
\text { (2019) }\end{array}$ & Qualitative & Interviews & Chinese MNCs & $\begin{array}{l}\text { HRM practices of Chinese MNCs are localized in USA } \\
\text { due to host country regulatory pressures and } \\
\text { avoidance of liability of origin }\end{array}$ & USA \\
\hline $\begin{array}{l}\text { Butt and } \\
\text { Katuse } \\
\text { (2017) }\end{array}$ & Qualitative & Interviews & $\begin{array}{l}\text { Subsidiaries in } \\
\text { Automotive } \\
\text { industry }\end{array}$ & $\begin{array}{l}\text { Polycentric approach and Host country cultural } \\
\text { challenges leads to localization }\end{array}$ & Pakistan \\
\hline $\begin{array}{l}\text { Chung }(20 \\
15)\end{array}$ & Qualitative & Interviews & $\begin{array}{l}\text { Japanese, USA } \\
\text { and South } \\
\text { Korea MNCs } \\
\text { subsidiaries }\end{array}$ & $\begin{array}{l}\text { USA firms had majority of HCN Managing Directors } \\
\text { unlike Japanese and South Korea who employed } \\
\text { expatriates from parent country. }\end{array}$ & European markets \\
\hline $\begin{array}{l}\text { Chen et al,. } \\
\text { (2005) }\end{array}$ & Quantitative & Questionnaires & $\begin{array}{c}\text { Japanese, } \\
\text { American and } \\
\text { European } \\
\text { based MNCs } \\
\text { subsidiaries }\end{array}$ & $\begin{array}{l}\text { Cultural and institutional characteristics of home } \\
\text { country influence HR adaptation strategy in host } \\
\text { country }\end{array}$ & Taiwan \\
\hline $\begin{array}{l}\text { Edwards et } \\
\text { al., (2016) }\end{array}$ & Quantitative & $\begin{array}{l}\text { Survey } \\
\text { Questionnaires }\end{array}$ & $\begin{array}{l}\text { Indigenous } \\
\text { and US owned } \\
\text { MNCs }\end{array}$ & $\begin{array}{l}\text { Institutions impose varied isomorphic pressures to } \\
\text { which MNCs have to conform to increase } \\
\text { organizational legitimacy }\end{array}$ & $\begin{array}{l}\text { UK, Canada, Spain, } \\
\text { Denmark and } \\
\text { Norway }\end{array}$ \\
\hline
\end{tabular}




\begin{tabular}{|c|c|c|c|c|c|}
\hline $\begin{array}{l}\text { Author(s) } \\
\text { and Year }\end{array}$ & Method & Tools & Sample & Summarized Findings & Country \\
\hline $\begin{array}{l}\text { Ayentimi et } \\
\text { al., (2017) }\end{array}$ & Qualitative & $\begin{array}{l}\text { In-depth -face- } \\
\text { to-face } \\
\text { interviews and } \\
\text { documents } \\
\text { analysis }\end{array}$ & $\begin{array}{l}5 \text { MNCs from } \\
\text { UK, France, } \\
\text { Germany and } \\
\text { India }\end{array}$ & $\begin{array}{l}\text { HRM practices i.e HRM structure and HRM Policy } \\
\text { orientation are similar to parent country due to } \\
\text { country-of-origin effect, competitive isomorphic } \\
\text { pressure, global integration, labour laws and colonial } \\
\text { upbringing }\end{array}$ & Ghana \\
\hline $\begin{array}{l}\text { Gooderham } \\
\text { et al., (2019). }\end{array}$ & Qualitative & $\begin{array}{c}\text { Documents } \\
\text { Published online }\end{array}$ & $\begin{array}{l}37 \text { samples of } \\
\text { articles }\end{array}$ & $\begin{array}{l}\text { Institutional distance between countries constrains } \\
\text { MNCs from adopting worldwide HRM policies. Even } \\
\text { US MNCs adapt their HRM practices to local } \\
\text { institutional settings }\end{array}$ & Worldwide \\
\hline $\begin{array}{l}\text { Farndale } e t \\
\text { al., (2017) }\end{array}$ & Quantitative & $\begin{array}{l}\text { The Cranet } \\
\text { questionnaire }\end{array}$ & $\begin{array}{l}\text { Multinational } \\
\text { Enterprises' } \\
\text { Subsidiaries in } \\
\text { LMEs and } \\
\text { CMEs, }\end{array}$ & $\begin{array}{l}\text { LMEs are the Anglo-Saxon societies (USA, UK, and } \\
\text { Australia) dominated by shareholder ownership, } \\
\text { focused on short term profit maximization, minimal } \\
\text { role of government, deregulated labour markets and } \\
\text { strong competition influence HRM standardization. } \\
\text { CMEs' typified by Germany have wider stakeholder } \\
\text { approach, higher regulation of labour market increase } \\
\text { localized practices. }\end{array}$ & $\begin{array}{l}\text { LMEs (UK and } \\
\text { Australia), and } \\
\text { MNEs in CMEs } \\
\text { (Denmark, Austria, } \\
\text { Belgium, Finland, } \\
\text { Germany, the } \\
\text { Netherlands and } \\
\text { Sweden) }\end{array}$ \\
\hline $\begin{array}{l}\text { Farndale et } \\
\text { al., (2008) }\end{array}$ & Quantitative & $\begin{array}{c}\text { Standard } \\
\text { questionnaire } \\
\text { on HRM }\end{array}$ & $\begin{array}{l}\text { Foreign MNCs, } \\
\text { domestic } \\
\text { MNCs and } \\
\text { domestic } \\
\text { companies }\end{array}$ & $\begin{array}{l}\text { Varieties of capitalism especially the liberal and } \\
\text { coordinated market economies } \\
\text { Liberal allow leeway of companies, diversity } \\
\text { practices while CMEs characterized by restrictions, } \\
\text { higher regulations and control of people management }\end{array}$ & $\begin{array}{l}\text { Liberal i.e UK and } \\
\text { Coordinated market } \\
\text { economies i.e } \\
\text { Germany, the } \\
\text { Netherlands and } \\
\text { Sweden) }\end{array}$ \\
\hline
\end{tabular}




\begin{tabular}{|c|c|c|c|c|c|}
\hline $\begin{array}{l}\text { Author(s) } \\
\text { and Year }\end{array}$ & Method & Tools & Sample & Summarized Findings & Country \\
\hline $\begin{array}{l}\text { Parry et al., } \\
\text { (2008) }\end{array}$ & Quantitative & Questionnaires & $\begin{array}{c}\text { North } \\
\text { American } \\
\text { owned MNCs } \\
\text { in Liberal } \\
\text { Market } \\
\text { Economies and } \\
\text { Coordinated } \\
\text { Market } \\
\text { Economies }\end{array}$ & $\begin{array}{l}\text { Results indicates that patterns of HR practices i.e } \\
\text { selection sophistication, investment in training, } \\
\text { individualized rewards, diversity programmes, trade } \\
\text { union recognition, direct communication indirect } \\
\text { communication pursued by North American owned } \\
\text { MNCs varies widely depending on whether these } \\
\text { North American owned MNCs operate in liberal or } \\
\text { coordinated market economies }\end{array}$ & $\begin{array}{l}\text { Liberal economies } \\
\text { (UK, Australia) } \\
\text { Coordinated } \\
\text { economies } \\
\text { (Germany, Sweden, } \\
\text { Denmark, the } \\
\text { Netherlands, USA } \\
\text { and Canada) }\end{array}$ \\
\hline
\end{tabular}

Table 2: Influence of Country-of-origin Dominance on Standardization and Localization of HRM Practices in MNCs' Subsidiaries

\begin{tabular}{|c|c|c|c|c|c|}
\hline Author(s) and Year & Method & Tools & Sample & \multicolumn{1}{c|}{ Summarized Findings } \\
\hline Edwards et. al., (2013) & Quantitative & Questionnaires & $\begin{array}{c}1,100 \text { subsidiaries in } \\
\text { four countries }\end{array}$ & $\begin{array}{l}\text { Dominance effects are indicated } \\
\text { first by the diffusion of practices } \\
\text { associated with dominant } \\
\text { economy which we take to be the } \\
\text { United States }\end{array}$ & $\begin{array}{c}\text { Canada, Ireland, } \\
\text { Spain and United } \\
\text { Kingdom } \\
\text { If dominance effects are present, } \\
\text { we expect evidence of US-style } \\
\text { practices }\end{array}$ \\
& & & & \\
& & & & \\
\end{tabular}




\begin{tabular}{|c|c|c|c|c|c|}
\hline Author(s) and Year & Method & Tools & Sample & Summarized Findings & Country \\
\hline $\begin{array}{l}\text { Pudelko and Wil- } \\
\text { Harzing (2007). }\end{array}$ & Quantitative & Mail questionnaires & $\begin{array}{c}\text { US, Japanese } \\
\text { subsidiaries and } \\
\text { German subsidiaries }\end{array}$ & $\begin{array}{l}\text { Subsidiary practices appear to } \\
\text { converge to the dominant US } \\
\text { practice. HRM practices are } \\
\text { neither shaped by country-of- } \\
\text { origin nor host country, but rather } \\
\text { according to the country that sets } \\
\text { the standards for what are } \\
\text { perceived to be global best } \\
\text { practices. }\end{array}$ & $\begin{array}{l}\text { Germany (US and } \\
\text { Japanese } \\
\text { subsidiaries), US and } \\
\text { German subsidiaries } \\
\text { in Japan and German } \\
\text { subsidiaries in USA }\end{array}$ \\
\hline $\begin{array}{l}\text { Jiang and Yahiaoui } \\
\text { (2019) }\end{array}$ & Qualitative & Interviews & $\begin{array}{l}16 \text { French MNCs } \\
\text { subsidiaries }\end{array}$ & $\begin{array}{l}\text { Majority of Companies' } \mathrm{HRM} \\
\text { practices were standardized }\end{array}$ & China \\
\hline $\begin{array}{c}\text { Savaneviciene \& } \\
\text { Kersiene, } 2015\end{array}$ & $\begin{array}{c}\text { Mixed } \\
\text { methods }\end{array}$ & $\begin{array}{l}\text { Interviews and } \\
\text { questionnaires }\end{array}$ & $\begin{array}{l}17 \text { USA MNCs } \\
\text { subsidiaries }\end{array}$ & $\begin{array}{l}\text { HRM practices in } 10 \text { MNCs' HRM } \\
\text { like leadership training, } \\
\text { standardized } \\
\text { programmmes, } \\
\text { selection, employee cross-cultural } \\
\text { competences, } \\
\text { evaluation, development models, } \\
\text { compensation, motivation and } \\
\text { employee engagement were } \\
\text { integrated in 10 MNCs due to } \\
\text { dominant economy of parent } \\
\text { country over host countries }\end{array}$ & Lithuania \\
\hline Cocul'ová (2015) & Quantitative & Questionnaires & MNCs subsidiaries & $\begin{array}{l}\text { Low rate of transfer of } \\
\text { recruitment and selection in } \\
\text { Slovak subsidiaries due to labour } \\
\text { markets, rate of unemployment }\end{array}$ & Slovakia \\
\hline
\end{tabular}


Table 3: International HRM Approaches as Determinants of Standardization and Localization of HRM Practices in MNCs' Subsidiaries

\begin{tabular}{|c|c|c|c|c|c|}
\hline Author(s) and Year & Method & Tools & Sample & $\begin{array}{l}\text { Summarized Findings } \\
\end{array}$ & Country \\
\hline Azungah (2017) & Qualitative & $\begin{array}{c}\text { Interviews with } \\
\text { employees and } \\
\text { managers }\end{array}$ & $\begin{array}{c}\text { Western } \\
\text { subsidiaries }\end{array}$ & $\begin{array}{l}\text { Ethnocentric practices affect succession planning, } \\
\text { training and development, contingent reward, } \\
\text { employee participation and Host country playing } \\
\text { roles in management styles of host country } \\
\text { nationals. HRM Practices standardization and } \\
\text { localization exist at varying degree. }\end{array}$ & Ghana \\
\hline Smerek et al. (2018) & Quantitative & Questionnaires & $\begin{array}{c}\text { MNCs placed } \\
\text { in CEE Top } \\
500\end{array}$ & $\begin{array}{l}\text { International HRM approaches i.e ethnocentric, } \\
\text { polycentric, transnational) plus development of } \\
\text { globalization, recognition of cultural and } \\
\text { institutional differences influence regiocentric } \\
\text { and geocentric HRM practices }\end{array}$ & Slovakia \\
\hline Touron (2008) & Qualitative & $\begin{array}{c}\text { In-depth } \\
\text { interviews }\end{array}$ & $\begin{array}{l}\text { Single Case } \\
\text { Study of } \\
\text { French } \\
\text { Multinational } \\
\text { Company }\end{array}$ & $\begin{array}{l}\text { Company changed its ethnocentric to geocentric } \\
\text { approach managerial staffing due to ethnocentric } \\
\text { inefficiency when sizes and geographic } \\
\text { expansions were undertaken } \\
\text { Globalization and geocentric approach are } \\
\text { interconnected. }\end{array}$ & $\begin{array}{l}\text { Host countries } \\
\text { where Anglo- } \\
\text { Saxon Companies } \\
\text { before acquisition } \\
\text { operated }\end{array}$ \\
\hline $\begin{array}{l}\text { Sarafin and Szamosi } \\
\text { (2015) }\end{array}$ & $\begin{array}{c}\text { Mixed } \\
\text { methods }\end{array}$ & $\begin{array}{c}\text { Quantitative } \\
\text { questionnaire and } \\
\text { semi-structured } \\
\text { interview }\end{array}$ & $\begin{array}{l}\text { Five Global } \\
\text { luxury hotel } \\
\text { subsidiaries }\end{array}$ & $\begin{array}{l}\text { Luxury hotel have been able to maintain an } \\
\text { overall uniform implementation of HRM policies } \\
\text { and practices regardless of locale socio-economic } \\
\text { differences; but facilitated by geocentric approach } \\
\text { illustrated by Perlmutter in } 1969 \text { seminal work }\end{array}$ & $\begin{array}{c}\text { Azerbaijan } \\
\text { (Caucasus), } \\
\text { Kyrgyzstan and } \\
\text { Germany }\end{array}$ \\
\hline
\end{tabular}

